\title{
Komunikasi Pemasaran Terpadu dalam Mengembangkan Kapasitas Petani Padi di Provinsi Banten
}

\author{
Integrated Marketing Communication to Develop Rice \\ Farmers' Capacity in Banten Province
}

\author{
Johan David Wetik ${ }^{1}$, Amiruddin Saleh ${ }^{2}$, Pang S. Asngari², Djuara P. Lubis ${ }^{2}$ \\ ${ }^{1}$ Sekolah Tinggi Ilmu Ekonomi Kalpataru Cibinong Bogor \\ ${ }^{2}$ Departemen Sains Komunikasi dan Pengembangan Masyarakat, Institut Pertanian Bogor, Bogor
}

\begin{abstract}
An integrated marketing communication suited to the development of communication technology has changed, such as that with the increasing use of the Internet. This will certainly also affect the agricultural actors (extension workers and farmers) in obtaining information on products or services. Farmers' capacity is the resources that they possess to establish and achieve the right objectives of farming. Every individual has an inherent capacity. In view of the farmers' ability to meet the needs with their own potential, the objectives of this study were: (1) to analyze the characteristics of entrepreneurship, integrated marketing communication, and farmer capacity; (2) to determine the factors that affect the farmer's capacity. This study uses a positivistic paradigm with a quantitative research methodology and a survey method. The research sites were in four regencies in Banten Province, namely Lebak, Serang, Pandeglang and Tenggerang. The population involved a total of 276,712 rice farmers. The number of samples was determined by the Slovin formula with an error rate of 5 percent, accounting for 400 people. The results showed that (1) the characteristics of the rice farmer's entrepreneurship is good enough, they have been able to apply an integrated marketing communication, and their capacity is good enough in running the business; (2) the capacity is directly influenced by the characteristics of entrepreneurship, and indirectly affected by an integrated marketing communication.
\end{abstract}

Keywords : Entrepreunership characteristic, integrated marketing communication, rice farmer capacity

\begin{abstract}
Abstrak
Komunikasi pemasaran sesuai dengan perkembangan teknologi proses komunikasi juga mengalami perubahan, seperti akhirakhir ini maraknya perkembangan internet. Tentunya ini juga akan berpengaruh terhadap pelaku pertanian baik penyuluh maupun petani dalam memperoleh informasi suatu produk atau jasa. Kapasitas petani adalah daya-daya yang dimiliki pribadi petani untuk dapat menetapkan tujuan usahatani secara tepat dan mencapai tujuan yang telah ditetapkan dengan cara yang tepat pula. Setiap individu (orang) secara alamiah selalu memiliki kapasitas yang melekat pada dirinya. Kemampuan petani untuk memenuhi kebutuhan sesuai dengan potensi yang dimiliki, maka tujuan penelitian ini adalah: (1) menganalisis karakteristik kewirausahaan, komunikasi pemasaran terpadu, dan kapasitas petani; (2) menganalisis faktor-faktor yang mempengaruhi kapasitas petani. Penelitian ini menggunakan paradigma positivistik dengan metodologi penelitian kuantitatif serta menggunakan motode survey. Lokasi penelitian berada di empat kabupaten di Provinsi Banten, yaitu Kabupaten Lebak, Kabupaten Serang, Kabupaten Pandeglang dan Kabupaten Tenggerang. Populasinya adalah petani padi dengan jumlah 276.712 orang. Jumlah sampel ditetapkan dengan rumus Slovin dengan tingkat error 5 persen, diperoleh sebanyak 400 orang. Hasil penelitian menunjukkan bahwa: (1) karateristik kewirausahaan petani padi sudah cukup baik, petani telah mampu melakukan komunikasi pemasaran terpadu, dan kapasita petani padi sudah cukup baik dalam menjalankan usaha; (2) kapasitas dipengaruhi secara langsung oleh karakteristik kewirausahaan, dan dipengaruhi secara tidak langsung oleh komunikasi pemasaran terpadu
\end{abstract}

Kata kunci : Kapasitas petani, komunikasi, pemasaran terpadu

\section{Pendahuluan}

Komunikasi pemasaran adalah sarana bagi organisasi atau lembaga berusaha menginformasikan, mengajak, dan mengingatkan konsumen secara langsung maupun tidak langsung tentang produk dan jasa. Komunikasi pemasaran mempresentasikan suara organisasi dan

${ }^{1}$ Korespondensi penulis

E-mail: johandwetik@yahoo.com lembaga serta merupakan sarana untuk dapat membuat dialog dan membangun hubungan dengan konsumen. Ada dua unsur pokok dalam komunikasi pemasaran, yaitu pertama komunikasi yang merupakan proses pemikiran dan pemahaman disampaikan antar individu, atau antar organisasi dengan individu. Komunikasi sebagai proses penyampaian pesan yang merupakan 
gagasan atau informasi pengirim melalui suatu media kepada penerima agar mampu memahami maksud pengirim. Unsur pokok kedua adalah pemasaran merupakan sekumpulan kegiatan organisasi atau lembaga mentransfer nilai-nilai (pertukaran) tentang informasi produk, jasa dan ide antara mereka dengan pelanggannya.

Berkaitan dengan pengembangan usahatani padi dan usaha sampingan pada petani padi, maka ada upaya menumbuhkan jiwa kewirausahaan petani dan ketrampilan komunikasi pemasaran terpadu yang dibutuhkan dalam pengembangan usaha, baik usahatani padi maupun usaha sampingan. Menumbuhkan jiwa kewirausahaan merupakan salah satu usaha yang bisa diharapkan untuk memacu pertumbuhan ekonomi pertanian. Jiwa kewirausahaan akan mengubah orientasi usahatani dari sekedar produksi menjadi berorientasi bisnis. Petani akan mulai mempertimbangkan jenis tanaman yang akan ditanam, waktu tanam dan bahkan sampai pada usaha pengolahan hasil pertanian dalam rangka memperoleh nilai tambah dari kegiatan tersebut, serta peningkatan usaha sampingan. Komunikasi pemasaran terpadu merupakan bagian didalam bauran pemasaran yakni: harga, produk, penempatan(distribusi) dan promosi. Promosi ini disebut dengan komunikasi yang bisa dilakukan untuk pembangunan pertanian dan pedesaan terdiri dari iklan, promosi penjualan, pengorganisasian acara, hubungan masyarakat dan publikasi, pemasaran langsung, pemasaran interaktif, pemasaran dari mulut ke mulut dan penjualan langsung (Kotler \& Keller 2009). Pembangunan pertanian dan pedesaan dapat melakukan integrasi didalam melakukan komunikasi. Integrasi bauran komunikasi (Integrated communications mix) merupakan kombinasi didalam menggunakan media komunikasi sehingga pengembangan usahatani padi dan usaha sampingan dapat mencapai tujuannya.

Komunikasi pemasaran terpadu merupakan konsep perencanaan komunikasi pemasaran yang menyadari nilai tambah dari suatu rencana komprehensif yang mengevaluasi peran strategis dari berbagai disiplin komunikasi semisal komunikasi umum, tanggapan langsung, promosi penjualan dan hubungan masyarakat serta menggabungkan berbagai disiplin ini untuk memberikan kejelasan, konsistensi dan pengaruh komunikasi yang maksimum melalui integrasi menyeluruh dari pesan-pesan yang berlainan (Belch \&
Belch 2009).

Sistem usaha pertanian tanaman pangan di Indonesia masih di dominasi oleh sistem pengelolaan rakyat. Sistem pengelolaan rakyat dicirikan dengan sebatas kantong- kantong produksi yang bersifat kawasan produksi, pertanamanmenggunakanteknologisederhana dan penggunaan informasi pasar belum memadai, modal terbatas, dan lebih bersifat individu. Usahatani tanaman pangan terutama padi memiliki ketergantungan tinggi terhadap preferensi konsumen (pasar), sehingga kondisi tersebut harus segera diperbaiki dan diubah agar dapat bersaing di pasar. Hingga saat ini perilaku petani dalam melaksanakan usaha pertanian selalu berpijak sesuai dengan kapasitas yang dimilikinya. Oleh karena itu perubahan tersebut harus berpijak dari kapasitas petani. Tanpa dimulai dari kapasitas, segala upaya yang dilakukan untuk keberhasilan usahatani tidak akan berhasil secara berkelanjutan.

Kapasitas petani adalah daya-daya yang dimiliki pribadi petani untuk dapat menetapkan tujuan usahatani secara tepat dan mencapai tujuan yang telah ditetapkan dengan cara yang tepat pula. Setiap individu (orang) secara alamiah selalu memiliki kapasitas yang melekat pada dirinya. Kemampuan petani untuk memenuhi kebutuhan sesuai dengan potensi yang dimiliki merupakan suatu kapasitas petani yang tidak boleh diabaikan apabila ingin keberhasilan usaha pertanian dapat berkelanjutan. Maka tujuan penelitian ini adalah:

1. Menganalisis karakteristik kewirausahaan, komunikasi pemasaran terpadu, dan kapasitas petani;

2. Menganalisis faktor-faktor yang mempengaruhi kapasitas petani.

\section{Metode Penelitian}

Penelitian ini menggunakan paradigma positivistik dengan metodologi penelitian kuantitatif serta menggunakan motode survey. Lokasi penelitian berada di empat kabupaten di Provinsi Banten, yaitu Kabupaten Lebak, Kabupaten Serang, Kabupaten Pandeglang dan Kabupaten Tenggerang. Populasinya adalah petani padi dengan jumlah 276.712 orang. Jumlah sampel ditetapkan dengan rumus Slovin dengan tingkat error $5 \%$, diperoleh sebanyak 400 orang (Tabel 1).

Teknik pengambilan sampel dari kabupaten hingga kelompok tani dilakukan dengan menggunakan 
purposive sampling dan pada responden dengan menggunakan stratified random sampling. Analisis data penelitian menggunakan statistik deskriptif dengan menggunakan tabel distribusi frekuensi dan statistika inferensial dengan analisis analisis path.

Tabel 1. Populasi dan Sampel Empat Kabupaten di Provinsi Banten

\begin{tabular}{lcc}
\hline Kabupaten & $\begin{array}{c}\text { Populasi } \\
\text { (Orang) }\end{array}$ & $\begin{array}{c}\text { Sampel } \\
\text { (Orang) }\end{array}$ \\
\hline Pandeglang & 91.800 & 105 \\
Lebak & 74.981 & 109 \\
Serang & 54.599 & 105 \\
Tangerang & 55.332 & 81 \\
\hline
\end{tabular}

\section{Hasil dan Pembahasan}

\section{Karakteristik Kewirausahaan}

Karakteristik kewirausaan petani padi di Provinsi Banten terkait dengan mandiri, berani mengambil resiko, keandalan pengelolaan usaha, inovasi, dan orientasi kedepan. Semua indikator tersebut berada pada kategori sedang (Tabel 2), artinya petani padi sudah cukup mandiri melakukan usaha, dan sudah mampu mengambil resiko didalam melaksanakan usaha, selain itu petani padi juga memiliki keandalan pengelolaan usaha, inovasi, serta memiliki orientasi ke masa depan.

\section{Mandiri}

Petani padi di Provinsi Banten sudah cukup mandiri dalam melakukan usaha. Hasil penelitian menunjukkan bahwa kemandirian petani padi pelaku usaha sampingan berada pada kategori sedang. Kemandirian dapat dilihat dari cara petani dalam melakukan usaha tanpa bergantung kepada orang lain, giat dalam bekerja, pantang menyerah dan memiliki kepercayaan diri yang tinggi. Senada dengan Suci (2009) menyatakan orientasi kewirausahaan dapat dilihat melalui keinginan untuk mencapai tujuan (need for achievement), keyakinan bahwa keberhasilan itu adalah karena usaha dari diri sendiri (internal locus of control), rasa percaya diri (self reliance), dan keterbukaan (extrovertion). Petani pelaku usaha sampingan melakukan usaha secara individu baik dari awal produksi hingga pemasaran. Pada umumnya, kemandirian dilihat dari pemasaran produk dimana pelaku usaha memasarkan produk sendiri ke pasar lokal. Pelaku usaha tidak bergantung kepada siapapun dalam menjual produknya karena sudah memperkirakan pasar sebelum menjual hasil produk usaha sampingan.

Selain itu, dalam melakukan usaha sampingan juga terkadang dilakukan secara mandiri tanpa bantuan orang lain, termasuk mencoba inovasi-inovasi agar mendapatkan hasil yang diinginkan pasar. Pelaku usaha melakukan tersebut secara mandiri karena memang belum ada bantuan yang diberikan terkait menunjang

Tabel 2. Karakteristik Kewirausaan Petani Padi di Provinsi Banten, 2018

\begin{tabular}{llrr}
\hline \multicolumn{1}{c}{ Karakteristik Kewirausahaan } & \multicolumn{1}{c}{ Kategori } & $\begin{array}{r}\text { Jumlah } \\
\text { (Orang) }\end{array}$ & $\begin{array}{c}\text { Persentase } \\
\text { (\%) }\end{array}$ \\
\hline Mandiri & \multicolumn{1}{c}{ Rendah $(13,998-17,322)$} & 58 & 14,50 \\
Rataan $=19$ & Sedang $(17,328-20,652)$ & 239 & 59,75 \\
& Tinggi $(20,658-24)$ & 103 & 25,75 \\
Berani Menggambil Resiko & Rendah $(12,996-17,322)$ & 20 & 5,00 \\
Rataan $=19$ & Sedang $(17,328-20,322)$ & 283 & 70,75 \\
& Tinggi $(20,328-24)$ & 97 & 24,75 \\
Keandalaan & Rendah $(15,000-20,656)$ & 25 & 6,25 \\
Rataan $=24$ & Sedang $(20,664-26,320)$ & 250 & 62,50 \\
& Tinggi $(26,328-320$ & 125 & 31,25 \\
Inovasi & Rendah $(9-12,660)$ & 19 & 4,75 \\
Rataan $=15$ & Sedang $(12,665-16,325)$ & 255 & 63,75 \\
Orientasi Kedepan & Tinggi $(16,330-20)$ & 126 & 31,50 \\
Rataan $=12$ & Rendah $(6-9,328)$ & 31 & 7,75 \\
& Sedang $(9,332-12,660)$ & 247 & 61,75 \\
& Tinggi $(12,664-16)$ & 122 & 30,50 \\
\hline
\end{tabular}


usaha sampingan sehingga semua proses produksi dilakukan secara individu sesuai dengan karakteristik usahanya. Pelaku usaha sampingan terus belajar sehingga sesuai dengan apa yang mereka inginkan

\section{Berani Mengambil Resiko}

Petani padi pelaku usaha sampingan sudah mampu mengambil resiko didalam melaksanakan usaha. Hasil penelitian menunjukkan hanya sebagian kecil yang tidak berani mengambil resiko. Keberanian mengambil resiko dilihat dari kemampuan dalam merencanakan sebelum melakukan usaha dan memperkirakan segala kemungkinan ketidakpastian usaha (Murisa \& Chikweche 2013).

Petani di Provinsi Banten berani dalam melakukan promosi produk yang mereka jual meskipun produknya masih kurang berkualitas jika dibandingkan dengan produk dari luar atau tetap mempromosikan produknya meskipun sudah banyak diketahui oleh konsumen. Adanya promosi tersebut seperti memberikan promo atau diskon sehingga banyak konsumen yang tertarik dengan produk tersebut. Pelaku usaha sampingan juga siap jika harus rugi karena memang itulah modal yang perlu bagi seorang pelaku usaha

\section{Keandalan}

Keandalan responden berada pada tingkatan sedang atau dapat dikatakan petani padi pelaku usaha sampingan memiliki keandalan dalam pengelolaan usaha. Keandalan ini dilihat dari pengorganisasian usaha dimulai dari proses perencanaan, efektif dalam mengelola waktu dan kemampuan menyelesaikan masalah. Petani pelaku usaha sampingan memiliki keandalan dalam menyelesaikan masalah seperti masalah kurangnya kuantitas produksi padi hitam sehingga perlu upaya untuk meningkatkan produksi padi tersebut yaitu dengan mengajak petani lain untuk menanam padi hitam. Keandalan dalam memasarkan hasil produksi, dimana jika dipasarkan ke tengkulak maka hasil yang didapatkan sedikit sehingga upaya dari pelaku usaha langsung menjual sendiri ke pasar atau mengikutkan pameran-pameran yang difasilitasi oleh kelompok. Mengenai perencanaan, pelaku usaha juga sudah handal dalam melihat peluang pasar seperti melakukan survey-survey untuk mengetahui produk apa yang dibutuhkan oleh pasar setempat.

\section{Inovasi}

Petani padi pelaku usaha sampingan pada karateristik kewirausahaan dalam inovasi berada pada tingkatan sedang. Penerapan inovasi dilakukan untuk terus mengikuti perkembangan dan keinginan konsumen. Inovatif dalam penelitian ini dimaksudkan sebagai kemampuan untuk melakukan solusi baru dan kreatif terhadap peluang serta mau mencoba sesuatu yang baru agar terlihat unik dan berbeda.

Senada dengan Wirastika et al. (2016) bahwa karakteristik psikologis kewirausahaan adalah pekerja keras, percaya diri, disiplin, berani mengambil resiko, toleransi terhadap ketidakpastian, inovatif, mandiri, dan bertanggung jawab. Petani pelaku usaha sampingan sudah melakukan hal tersebut sebagaimana petani yang mulanya hanya memproduksi padi merah sekarang melihat peluang besar di padi hitam beralih menanam padi hitam. Selain itu, usaha sampingan telor asap yang jarang di Banten juga mulai dilakukan usaha sampingan tersebut.

\section{Orientasi Kedepan}

Petani pelaku usaha sampingan memiliki orientasi masa depan. Hal ini terlihat dari penelitian yang menunjukkan bahwa tingkat orientasi masa depan pelaku usaha berada pada tingkat sedang. Orientasi masa ke depan dilihat berdasarkan motif berprestasi, wawasan ke depan, jaringan kerja dan pemasaran yang dilakukan (Zimmere \& Scarborough 2007). Pelaku usaha sampingan khususnya di bidang ternak melakukan kerjasama dengan perusahaan sehingga pelaku usaha tidak rugi dalam usahanya karena di dukung oleh perusahaan. Hal ini menunjukkan ada jaringan kerja antara pelaku usaha dengan perusahaan sehingga orientasi ke depan sangat diperhitungkan oleh pelaku usaha

\section{Komunikasi Pemasaran Terpadu}

Indikator pada komunikasi pemasaran terpadu terkait dengan periklanan, peristiwa dan pengalaman, promosi penjualan, dan pemasaran interaktif, penjualan langsung. Berdasarkan indikator yang ditetapkan dapat dilihat bahwa petani telah mampu melakukan komunikasi pemasaran terpadu, hal ini terlihat dari semua indikator menunjukkan bahwa petani padi berada pak kategori sedang cenderung tinggi (Tabel 3). 
Tabel 3. Petani Komunikasi Pemasaran Terpadu Petani Padi di Provinsi Banten, 2018

\begin{tabular}{llrr}
\hline Komunikasi Pemasaran Terpadu & \multicolumn{1}{c}{ Kategori } & $\begin{array}{r}\text { Jumlah } \\
\text { (Orang) }\end{array}$ & $\begin{array}{c}\text { Persentase } \\
(\%)\end{array}$ \\
\hline Periklanan & Rendah $(19,998-25,317)$ & 48 & 12,00 \\
Rataan $=30$ & Sedang $(25,326-30,645)$ & 221 & 55,25 \\
& Tinggi $(30,654-36)$ & 131 & 32,75 \\
Peristiwa Dan Penggalaman & Rendah $(18,999-24,651)$ & 19 & 4,75 \\
Rataan $=31$ & Sedang $(24,660-30,312)$ & 155 & 38,75 \\
& Tinggi $(30,321-36)$ & 226 & 56,50 \\
Promosi Penjualan & Rendah $(18-23,985)$ & 42 & 10,50 \\
Rataan =31 & Sedang $(23,994-29,979)$ & 187 & 46,75 \\
& Tinggi $(29,988-36)$ & 171 & 42,75 \\
Pemasaran Interaktif & Rendah $(10-13,325)$ & 13 & 3,25 \\
Rataan $=17$ & Sedang $(13,330-16,655)$ & 185 & 46,25 \\
Penjualan Langsung & Tinggi $(16,660-20)$ & 202 & 50,50 \\
Rataan $=28$ & Rendah $(16-21,320)$ & 4 & 1,00 \\
& Sedang $(21,328-26,648)$ & 82 & 20,50 \\
& Tinggi $(26,656-32)$ & 34 & 78,50 \\
\hline
\end{tabular}

\section{Periklanan}

Periklanan dimaksudkan sebagai penggunaan media dalam memasarkan produk yang dihasilkan dalam usahatani dan usaha sampingan. Media yang digunakan dalam memasarkan produk baik usahatani maupun usaha sampingan yang dilakukan oleh petani di Banten yaitu media online khususnya melalui Facebook dan Whatsapp. Penggunaan media ini sesuai dengan kebutuhan dari konsumen terkadang ada yang menggunakan Facebook dan Whatsapp. Whatsapp sangat interaktif dan sering digunakan oleh pelaku usaha untuk menjual produk yang dihasilkan. Promosi melalui media sosial untuk menjangkau sasaran yang lebih luas

\section{Peristiwa dan Pengalaman}

Peristiwa dan pengalaman dimaksudkan sebagai upaya pemasaran yang dilakukan oleh pelaku usaha melalui pameran dan forum diskusi yang dilakukan. Petani sering memasarkan produk ke pameran-pameran yang dilaksanakan oleh pemerintah setempat baik di tingkat dinas level kabupatan maupun provinsi hingga tingkat kementerian. Pelaksanaan biasanya dilakukan oleh seorang dari kelompok baik ketua kelompok maupun pengurus. Produk dikumpulkan terlebih dahulu kemudian baru di bawa ke pameran-pameran yang diadakan. Upaya pemasaran melalui forum diskusi yang dilakukan seperti saat ada rapat atau pertemuan kelompok, hasil-hasil produksi dipamerkan

\section{Promosi Penjualan}

Promosi penjualan sebagai komunikasi pemasaran responden berada pada tingkat sedang meskipun tidak berbeda jauh dengan tingkatan tinggi. Promosi merupakan suatu tindakan yang penting dalam mendukung penjualan suatu produk (Reinold \& Tropp 2010). Promosi penjualan dimaksudkan sebagai metode pemberian potongan harga terhadap produk yang dihasilkan baik untuk usahatani atau usaha sampingan. Pelaku usaha sering memberikan diskon agar konsumen tetap sedia membeli produk yang dihasilkan. Selain itu potongan harga diberikan bagi yang ingin membantu memasarkan hasil usaha. Potongan harga baru dilakukan bagi produk usaha sampingan sedangkan untuk usahatani belum dilakukan karena usahatani hasilnya belum sesuai dengan keinginan petani karena harganya juga sudah ditentukan pemerintah

\section{Pemasaran Interaktif}

Pemasaran interaktif merupakan suatu kegiatan yang secara online untuk mempertautkan pelanggan secara langsung dan tidak langsung. Pelaku usaha melakukan pemasaran secara langsung melalui penggunaan aplikasi Whatsapp yang mudah diakses dan hampir seluruh petani memiliki telepon genggam berbasis Android. Penggunaan aplikasi ini dilakukan untuk menghubungkan petani dengan pembeli langsung dan mengetahui kebutuhan atau sesuatu yang diinginkan 
konsumen secara cepat. Pada praktik penerapannya, konsumen bertanya kepada petani produk yang dibutuhkan, jika produk tersebut tersedia maka petani akan langsung mengirimkan kepada konsumen artinya secara langsung.

Selain itu, jika tidak tersedia, petani akan memberikan informasi kebutuhan konsumen kepada petani lain melalui grup Whatsapp kemudian jika produk tersedia maka petani tersebut akan menyampaikan kepada konsumen. Selain Whatsapp, aplikasi berbasis daring yang digunakan oleh pelaku usaha di Banten yaitu Facebook. Kegunaan dan penerapannya sama seperti Whatsapp.

\section{Penjualan Langsung}

Penjualan langsung sebagai komunikasi pemasaran yang dilakukan oleh petani padi pelaku usaha sampingan berada pada kategori tinggi. Penjualan langsung dimaksudkan sebagai suatu interaksi tatap muka baik untuk pembelian maupun pemesanan usahatani dan usaha sampingan. Penjualan secara langsung dilakukan karena memang sudah sangat konvensional yang dilakukan dari awal usaha. Penjualan dilakukan dengan cara dijual langsung ke pasar, tengkulak dan ke konsumen langsung.

\section{Kapasitas Petani Padi dalam Menjalanakan Usaha}

Kapasitas merupakan kemampuan petani padi dalam menjalankan usaha (Subagio et al. 2008), dan hal ini dapat dilihat dari petani mengidentifikasi potensi diri, kemampuan mengembangkan pemasaran, kemampuan memecahkan masalah, dan kemampuan menjaga keberlanjutan usaha, dari semua indikator diketahui petani telah memiliki kapasitas yang cukup baik, hal ini terlihat dari sebagian besar petani padi berada pada kategori sedang (Tabel 4).

\section{Mengidentifikasi Potensi}

Kapasitas petani dalam mengidentifikasi potensi berada pada tingkat sedang. Mengidentifikasi potensi dilihat berdasarkan kemampuan terhadap sumber-sumber informasi yang tepatuntuk keperluan usaha, kemampuan dalam menggunakan pengalaman untuk perencanaan usaha dan pengetahuan terhadap penyebab kegagalan serta keberhasilan usaha. Kapasitas petani pelaku usaha dalam mencari informasi masih terbatas kepada penyuluh pertanian setempat. Penyuluh menjadi ujung tombak informasi, kebutuhan informasi pelaku usaha disampaikan kepada penyuluh kemudian penyuluh berusaha mengakses informasi tersebut.

Pelaku usaha memiliki kapasitas dalam hal perencanaan dan keberhasilan usaha. Hal ini terlihat dari cara pelaku usaha belajar dari pengalaman yang dialami selama melakukan usaha. Apa yang terjadi saat ini menjadi contoh untuk usaha ke depan sehingga pelaku usaha dapat merencanakan usaha ke depan baik itu karena kegagalan maupun menambah keberhasilan dari usahanya. Disinilah terlihat bahwa petani pelaku usaha sampingan memiliki kapasitas dalam hal mengidentifikasi potensi yang mereka miliki meskipun belum menjangkau ke semua kapasitas yang harus dimiliki oleh pelaku usaha.

Tabel 4. Kapasitas Petani Padi di Provinsi Banten, 2018

\begin{tabular}{llcc}
\hline \multicolumn{1}{c}{ Kapasitas Petani } & \multicolumn{1}{c}{ Kategori } & $\begin{array}{c}\text { Jumlah } \\
\text { (Orang) }\end{array}$ & $\begin{array}{c}\text { Persentase } \\
(\mathbf{\%})\end{array}$ \\
\hline Mengidentifikasi Petani & Rendah $(20,997-25,983)$ & 32 & 8,00 \\
Rataan $=29$ & Sedang $(25,992-30,978)$ & 263 & 65,75 \\
& Tinggi $(30,987-36)$ & 105 & 26,25 \\
Kemampuan Menggembangkan Pemasaran & Rendah $(60-79,950)$ & 55 & 13,75 \\
Rataan $=90$ & Sedang $(79,980-99,930)$ & 269 & 67,25 \\
& Tinggi $(99,960-120)$ & 76 & 19,00 \\
Kemampuan Memecahkan Masalah & Rendah $(25,992-33,312)$ & 63 & 15,75 \\
Rataan $=37$ & Sedang $(33,324-40,644)$ & 251 & 62,75 \\
& Tinggi $(40,656-48)$ & 86 & 21,50 \\
Kemampuan menjaga keberlanjutan & Rendah $(41,994-51,966)$ & 35 & 8,75 \\
Rataan $=56$ & Sedang $(91,984-61,956)$ & 295 & 73,75 \\
& Tinggi $(61,974-72)$ & 86 & 17,50 \\
\hline
\end{tabular}




\section{Pengembangan Pemasaran}

Kapasitas petani dalam mengembangkan pemasaran berada pada tingkat sedang. Kapasitas pengembangan pasar dilihat dari tingkat pengetahuan tentang informasi dan inovasi yang tepat, menggunakan informasi dan inovasi untuk tujuan usaha serta sikap penilaian setiap perubahan dari permintaan pasar sebagai peluang untuk dimanfaatkan. Pada tingkatan ini, petani pelaku usaha sampingan belum sepenuhnya mengerti tatacara pengembangan pemasaran. Pelaku usaha di Banten masih belum dapat menyediakan produk yang diinginkan konsumen berdasarkan kontonuitas produk.

Produk yang dihasilkan memang berkualitas namun ketika produk diminta oleh konsumen baik dalam jumlah yang banyak maupun rutinitas permintaan, masih banyak pelaku usaha yang tidak bisa menjamin kebutuhan tersebut. Selain itu, masih banyak pelaku usaha yang belum paham mengenai cara melihat peluang pasar, pelaku usaha hanya paham tatacara produksi namun tidak ditunjang dengan kapasitas dalam hal pengembangan pasar.

\section{Memecahkan Masalah}

Kapasitas petani dalam memecahkan masalah berada pada kategori sedang. Kapasitas dalam memecahkan masalah berdasarkan tingkat pengetahuan informasi yang berkaitan dengan masalah yang dihadapi, penggunaan informasi untuk pemecahan masalah tersebut dan sikap antisipatif terhadap setiap perubahan usaha dan kreativitas membuat pilihan usaha yang lebih menguntungkan. Pelaku usaha memiliki kapasitas dalam hal mengidentifikasi masalah dimana pelaku usaha mengetahui segala macam permasalahan yang dihadapi (Fatchiya 2010). Permasalahan tersebut mulai dari kegiatan produksi dimana kendala hama penyakit di tumbuhan atau ternak maupun usaha lainnya seperti sulitnya mencari bahan baku usaha dan permodalan hingga kendala pemasaran termasuk membuat kemasan produk dan promosi.

Segala persoalan dapat diidentifikasi dengan mudah oleh pelaku usaha namun berbanding terbalik dalam hal kemampuan memecahkan masalah dimana pelaku usaha sangat bergantung pada pihak lain baik itu kelompok maupun pemerintah (penyuluh). Segala macam persoalan disampaikan dalam kelompok dan penyuluh baru kemudian didapatkan solusi dari untuk memecahkan masalah tersebut. Antisipasi usaha juga masih tergolong rendah dimana pelaku usaha biasanya menunggu terjadi dulu baru kemudian diselesaikan masalah tersebut, belum ada upaya untuk mengantisipasi atau meminimalisir masalah yang diprediksi dapat terjadi.

\section{Menjaga Keberlanjutan}

Kapasitas petani dalam menjaga keberlanjutan usaha berada pada kategori sedang. Kapasitas mengenai menjaga keberlanjutan dilihat berdasarkan pengetahuan mengenai pengelolaan sumber daya yang tepat, pemahaman tentang kebutuhan sumberdaya alternatif dan tingkat keselarasan informasi yang digunakan dengan sumber daya yang dimiliki. Kiptot dan Franzel (2015) menyatakan pengembangan kapasitas sangat ditentukan oleh peluang usaha yang berkelanjutan. Pemahaman menjaga keberlanjutan usaha dapat dilihat dari pemanfaatan sumber daya air yang dilakukan oleh petani pada usahataninya, sedangkan untuk sumberdaya pada usaha sampingan masih belum terlalu terlihat pengelolaannya.

Pada usahatani padi, air menjadi kebutuhan yang sangat diperlukan sehingga harus dikelola secara maksimal. Pemanfaatan air tidak hanya untuk mengairi persawahan tapi juga untuk usaha mina padi. Banyaknya air dimanfaatkan untuk membesarkan ikan sehingga nantinya bisa di panen bersamaan. Selain itu, untuk menjaga air, petani juga berperan besar dalam menjaga lingkungan seperti tidak membuang sampah di irigasi. Petani harus menumpuk sampah kemudian dikumpulkan lalu dibuang ke bak penampungan.

\section{Faktor yang Memengaruhi Kapasitas Petani}

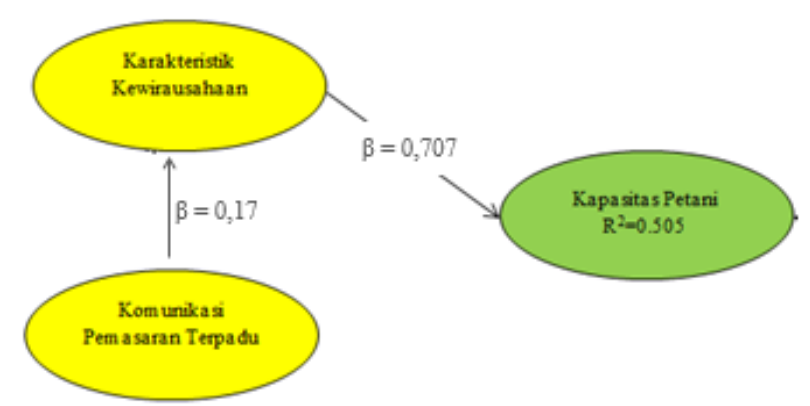

Gambar 1. Hasil Path Analysis Faktor-faktor yang Berpengaruh terhadap Kapasitas Petani, 2018 
Tabel 5. Nilai Koefisien Regresi Karakteristik Kewirausahaan terhadap Kapasitas Petani, 2018

\begin{tabular}{|c|c|c|c|c|c|}
\hline \multirow[b]{2}{*}{ Karakteristik Kewirausahaan } & \multicolumn{5}{|c|}{ Niai Koefisien $(\beta)$ terhadap Kapasitas Petani } \\
\hline & $\begin{array}{l}\text { Mengidenti } \\
\text { Fikasi }\end{array}$ & $\begin{array}{l}\text { Mengem } \\
\text { bangkan }\end{array}$ & $\begin{array}{l}\text { Memecahkan } \\
\text { Masalah }\end{array}$ & $\begin{array}{c}\text { Keber } \\
\text { lanjutan }\end{array}$ & $\begin{array}{l}\text { Kapasitas } \\
\text { Petani }\end{array}$ \\
\hline Mandiri & $0,42 * *$ & $0,50 * *$ & $0,48 * *$ & $0,38 * *$ & $0,45^{* *}$ \\
\hline Keberanian & $0,46^{* *}$ & $0,48 * *$ & $0,53 * *$ & $0,42 * *$ & $0,47 * *$ \\
\hline Keandalan & $0,47 * *$ & $0,68^{* *}$ & $0,57 * *$ & $0,42 * *$ & $0,53 * *$ \\
\hline Inovasi & $0,34 * *$ & $0,43^{* *}$ & $0,42 * *$ & $0,30 * *$ & $0,38 * *$ \\
\hline Orientasi & $0,16^{* *}$ & $0,37 * *$ & $0,34 * *$ & $0,24 * *$ & $0,28 * *$ \\
\hline Karakteristik Kewirausahaan & & & & & $0,68^{* *}$ \\
\hline $\begin{array}{ll}\text { Keterangan: } & * \text { Berpengaruh nyat } \\
& * * \text { Berpengaruh sang }\end{array}$ & $\begin{array}{l}\alpha=0,05 \\
\text { ta pada } \alpha=0\end{array}$ & & & & \\
\hline
\end{tabular}

Hasil dari analisis path diperolah bahwa kapasitas petani dipengaruhi secara langsung oleh karakteristik kewirausahaan, dan komunikasi pemasaran berhubungan dengan karakteristik kewirausahaan. Komunikasi pemasaran terpadu berpengaruh tidak langsung terhadap kapasitas petani seperti pada Gambar 1.

Karakteristik kewirausahaan mempunyai pengaruh yang cukup tinggi $(50,5 \%)$ terhadap kapasitas petani. Karakteristik kewirausahaan akan lebih terlihat dalam meningkatkan kapasitas petani dalam pengembangan pasar dan memecahkan masalah sebagaimana tertera pada Tabel 5.

Adapun persepsi komunikasi pemasaran terpadu tidak mempunyai pengaruh terhadap kapasitas petani tetapi berpengaruh terhadap karakteristik kewirausahaan. Hal ini disebabkan dalam mengidentifikasi potensi dan mengatasi permasalahan penggunaan komunikasi pemasaran terpadu tidak menjadi sesuatu hal yang utama. Berdasarkan kondisi tersebut, maka peningkatan persepsi komunikasi pemasaran terpadu hanya bisa dicapai melalui peningkatan karakteristik kewirausahaan.

Peningkatan kapasitas petani padi dapat dilakukan dengan terlebih dahulu meningkatkan persepsi komunikasipemasaranterpadumelaluipeningkatan karakteristik kewirausahaan. Sejalan dengan penelitian Hermanto dan Swastika (2011), bahwa dengan pelatihan keterampilan berkomunikasi akan meningkat kapasitas petani.

\section{Kesimpulan}

Karateristik kewirausahaan petani padi sudah cukup baik yaitu dalam kategori sedang. Petani telah mampu melakukan komunikasi pemasaran terpadu hal ini terlihat dari semua indikatornya dalam kategori sedang cendrung tinggi. Kapasitas petani padi sudah cukup baik dalam menjalankan usaha terlihat dari semua indikator dalam kategori sedang.

Kapasitas dipengaruhi secara langsung oleh karakteristik kewirausahaan, dan dipengaruhi secara tidak langsung oleh komunikasi pemasaran terpadu. Peningkatan kapasitas petani padi dilakukan dengan terlebih dahulu meningkatkan persepsi komunikasi pemasaran terpadu melalui peningkatan karakteristik kewirausahaan.

\section{Daftar Pustaka}

Belch G, Belch MAE. 2009. Advertising and Promotion: An Integrated Marketing Communication Perpective. 8th Edition. New York: McGraw-Hill.

Fatchiya A. 2010. Tingkat kapasitas pembudidaya ikan dalam mengelola usaha akuakultur secara berkelanjutan. Jurnal Penyuluhan 6 (1): 67-75.

Hermanto, dan Swastika DKS. 2011. Penguatan kelompok tani langkah awal peningkatan kesejahteraan petani. Jurnal Analisis Kebijakan Pertanian. 9(4): 371-390.

Kiptot E, dan Franzel S. 2015. Farmer to farmer extension: opportunities for enhancing performance of volunteer farmer trainers in Kenya. Journal Development in Practice. 25(4): 503-517. DOI: 10.1080/09614524.2015.1029438

Kotler, Keller. 2009. Manajem en Pemasaran. Erlangga: Jakarta.

Murisa T, dan Chikweche T. 2013. Entreprenership and micro finance in extreme Poverty challanges 
and prospect the case of Zimbabwe. Journal of Developmental Entrepreunership. 18(1):1-30.

DOI 10.1142/51084946713500015.

Reinold T, dan Troupp J. 2010. Integrated marketing communication, how can we measure its effectivesness. Journal of marketing communications. 18(2): 113-132

Subagio H, Sumardjo, Ashangari PS, Tjiptopranoto P, dan Santoso D. 2008. Kapasitas petani dalam mewujudkan keberhasilan usaha pertanian: Kasus petani sayuran Di Kabupaten Pasuruan dan Kabupaten Malang Provinsi Jawa Timur. Jurnal Penyuluhan 4 (1): 11-20.

Suci RP. 2009. Peningkatan kinerja melalui orientasi kewirausahaan, kemampuan manajemen, dan strategi bisnis: Studi pada industri kecil menengah bordir di Jawa Timur. Jurnal Manajemen Kewirausahaan. 5(2):25-40.

Wirastika NMS, Suwarsinah HK dan Lukman MB. 2016. Pengaruh Karakteristik Kewirausahaan terhadap Kinerja Usaha Mikro, Kecil dan Menengah(UMKM) Gula Aren di Kabupaten Lombok Barat. Jurnal Penyuluhan. (12)1.

Zimmere WT, Scarborough MN. 2007. Essential of Entrepreneurship And Small Business Management. Third Editional. New York (US): Prentice Hall. 